\title{
Waving the Magic Wand: An Argument for Reorganizing the Aridlands around Watersheds
}

\author{
Danika Cooper
}

SUSTAINABILITY

\begin{abstract}
Irrigation remains the primary means of sustaining urbanization and stabilizing agricultural productivity in arid America. In the contest for the West, water is both wealth and power. Today's struggle to overturn water scarcity is traceable through a long history of legislation overseeing land regulation, property speculation, societal development, and cultural attitudes, real and perceived, inscribed within the America's aridlands. In reality, there is no magic wand - no miraculous technology - that alone will fulfill the needs of all who have been promised abundance in the aridlands. This paper proposes that revisiting John Wesley Powell's 1893 proposal for aridland development in the context of today's ecological conditions catalyzes an alternative response to today's predictions of changing climates, and can provide the basis of an approach to the aridlands which builds from the enmeshed relationship between social and environmental systems.
\end{abstract}

Keywords: American West, aridity, aridland development, climate change, landscape planning

"And what do you do about aridity, if you are a nation inured to plenty and impatient of restrictions and led westward by pillars of fire and cloud? You may deny it for a while. Then you must either adapt to it or try to engineer it out of existence."

Wallace Stegner, "Living Dry" (1986)

In 1893, Secretary of the Interior John W. Noble boasted that the United States would undoubtedly expand in both ambition and population to 
become an empire unparalleled by any other in history. He believed the key to such dominance was the development of newly "discovered" land to the west of the 100th meridian. Undeterred by reports of the West's vast openness, unrecognizable ecologies, harsh climate, and unfamiliar people, Noble believed that the growth of the nation would instead depend on the development and cultivation of those very lands. He asserted that through its conquest over the foreign landscape and people, America would finally manifest its destiny as an unstoppable empire of liberty, freedom, and prosperity; he declared, "Irrigation is the magic wand which is to bring about these great changes." ${ }^{1}$ His predictions proved prescient - largescale irrigation projects were deployed throughout the Western frontier, supplanting the use of nearly all other strategies for water management, even those developed in direct response to arid conditions. As America expanded westward, aridlands were ruthlessly transformed through engineered water systems into places more recognizable and profitable for an agrarian, capitalist America. Noble's claim, nearly 130 years ago, remains a glaring reminder that the aridlands of the American West have historically been valued because of their potential to be transformed into a resource aimed to satisfy the needs and aspirations of America. And, its aridity has always been merely an engineering problem in need of a solution.

Today, irrigation continues to be the primary means of sustaining urbanization and stabilizing economic productivity in arid America. In the context of these irrigated regions, water is both wealth and power. Under the constant threat of imminent water crises, clashes between the diverse interest groups have intensified as solutions to scarcity - Noble's proverbial "magic wand" - become less and less obvious. At all levels of policy, efforts to divvy up water, advance market interests, and control labor and resource profitability are met with contradictory agendas from governments, Indigenous nations, corporations, advocacy organizations, and individuals.

Over the last two centuries, the mechanics and spatial requirements of irrigation have not only physically transformed the landscape's spatial logic and ecologic conditions but have also necessitated new socio-political patterns and interactions in the aridlands. Accordingly, irrigation is not only a technocratic solution to scarcity but instead a powerful socio-political actant. $^{2}$ Today's struggle to overturn water scarcity is traceable through a long history of legislation overseeing land regulation, property speculation, societal development, and cultural attitudes, real and perceived, inscribed within the America's aridlands. In reality, there is no magic wand, no miraculous technology that alone will fulfill the needs of all who have been promised abundance. But, probing history as a method of research offers insight into past ideas about, attitudes toward, and agendas for America's aridlands that are necessary in order to propose a future that is more resilient to changing socio-ecological conditions. 
Aridlands currently account for $46.2 \%$ of the global land area. ${ }^{3}$ In the United States, these lands currently cover about a third of the nation's landmass. The Intergovernmental Panel on Climate Change (IPCC), which warns that at the current rate, the global climate will warm $1.5^{\circ} \mathrm{C}\left(34.7^{\circ} \mathrm{F}\right)$ between 2030 and 2052, ${ }^{4}$ forecast that "warming climate will result in regional increases in the spatial extent of the drylands under mid- and high-emission scenarios and that these regions will warm faster than the global average warming rate." ${ }^{5}$ Warming conditions in the arid lands will result in reduced precipitation rates, soil moisture, and runoff, causing increased frequencies of droughts that will set in quicker, be more intense and widespread, last longer, and produce increased aridity, globally. ${ }^{6}$ Currently, approximately $70 \%$ of all the ground and surface water harvested is used for irrigation. ${ }^{7}$ The IPCC has shown that simultaneous with increased temperatures, the global population will increase to approximately 9.8 billion people by 2050 and 11.2 billion by 2100 , putting extreme pressure on natural resources, water, food supplies, and land systems. ${ }^{8}$ In order to address these longterm and dramatic socio-ecological changes caused by human activities in America's arid regions and those across the globe, a continuation of present processes, power structures, and human interactions will not suffice. Rather, there must be a reorientation away from conventional technocratic approaches toward a new kind of economic and socio-political system that is responsive to the ecological realities of heightened temperatures, decreased water availability, and increasing populations. Water must become the primary organizational principle in the aridlands, and its temporal cycles and flows should determine the quantity of water available, how and when water is distributed, and which land uses it will support.

To support this proposition, John Wesley Powell's recommendations for aridland development in his seminal publication The Arid Lands (1878) and specifically his Map of the Arid Region of the United States, Showing Drainage Districts (1890) are analyzed through this paper to provide clues for a more resilient arid future in the face of the growing climate crisis (Fig. 1). Three approaches structure Powell's vision for aridland development: that lands should be parceled and divided according to the ecological and social contexts; that water should be a public resource to be managed equitably; and finally, that land use should be determined by location, topography, and proximity to water. These suggestions were dramatic deviations from the status quo of their time which remain the status quo of today. Had they been implemented, the irrigated regions of the American West would be fundamentally and profoundly different, not just in the ways that water is managed but also in the ways that those in the West live and govern themselves, understand their relationship with nature, and approach economic development. Revisiting each of these recommendations and interpreting them in the context of current conditions catalyzes an alternative response to today's predictions of changing climates and can provide the basis of an approach to the aridlands which builds from the enmeshed relationship between social and environmental systems. 


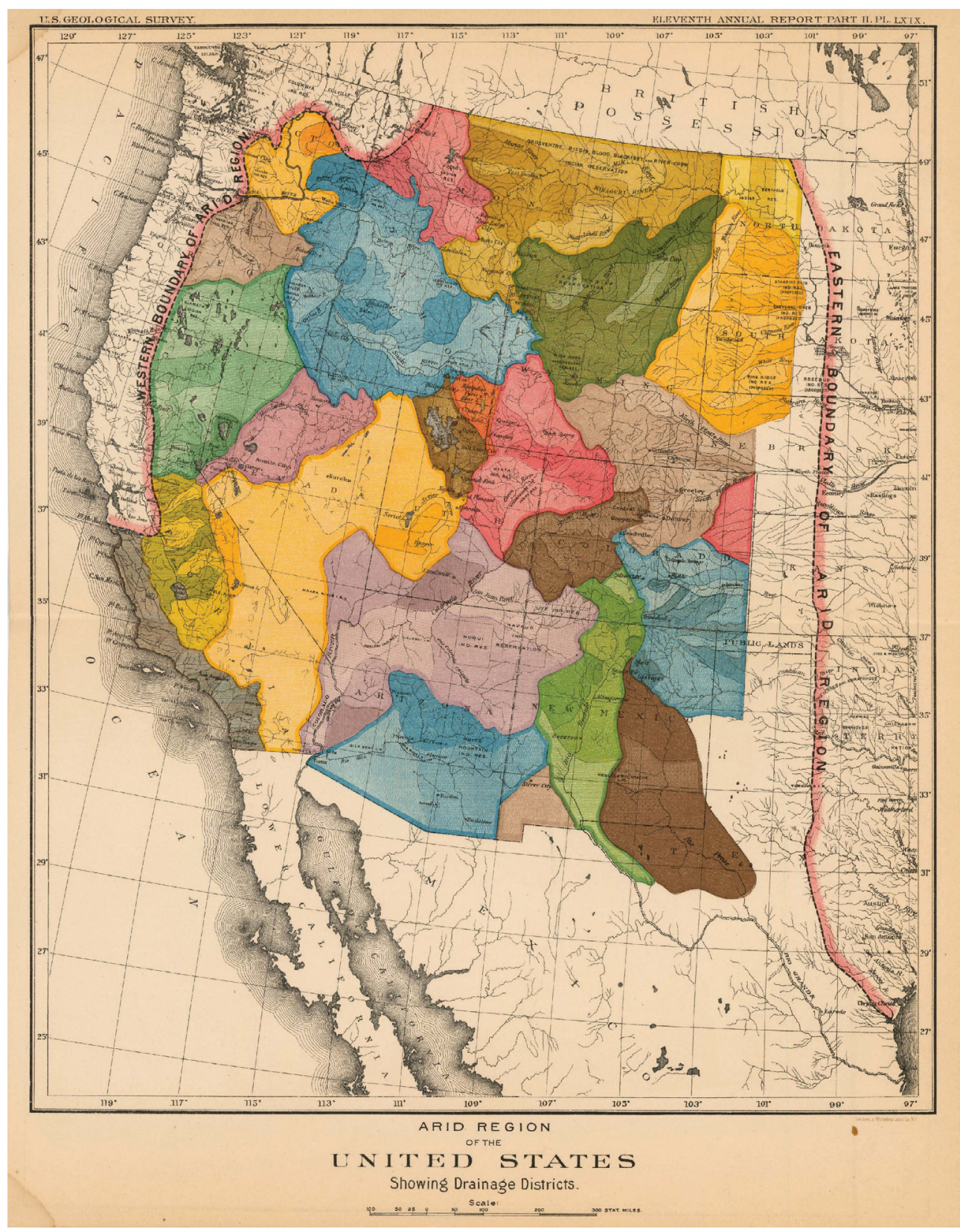

Figure 1. Under the directorship of John Wesley Powell, the United States Geological Survey of 1890 included a map of the aridlands organized around watersheds boundaries rather than state lines - it proposed a development strategy that responded to ecological and hydrological conditions. The proposal was altogether rejected with development modeled after efforts in more temperate climates.

\section{POWELL'S PROPOSAL: FRAMING THE WATERSHED AS NEW FORM FOR THE ARIDLANDS}

The aridlands have developed as a direct consequence of the values held by those with political power and the settler communities that inhabited these spaces. A study of these values, from the earliest settlers to those who occupy the region today, reveals that settlers believe the arid ecology 
can be tamed and should be transformed through engineering and technology in order to function in similar ways to other more temperate places. ${ }^{9}$ The scarcity of water is a problem that can be solved by bringing water into dry places and carefully controlling it. ${ }^{10}$ In reality, in order to live with a new climate regime, we need to reassess the values that have guided the past in order to rethink the future. Disrupting the status quo by radically rethinking how the aridlands are imagined, planned, and lived in, is not inconsequential - it would dramatically disrupt millions of people who are dependent and deeply invested in the existing hydraulic systems and the lifestyles it affords. Many of the existing approaches toward the aridlands and its water availability would be overturned, and a new set of values would need to be formed and cultivated. Nevertheless, the IPCC's predictions for changing precipitation rates, increased extreme weather, and increased populations are urgent and preclude us from being timid about new proposals. Instead, we will need an ambitious and radical reconfiguration of spatial, social, and political systems if we are to continue living in the aridlands under these changing conditions.

Revisiting John Wesley Powell's work within our present context of rising temperatures and increased dryness reveals important cues for moving forward that combine ecological conditions with social values. Powell was a one-armed Civil War hero, explorer, conservationist, geologist, and nineteenth-century celebrity, whose historical importance is demonstrated by the number of monuments, geographic features, and towns that share his name. His adventures through the Rocky Mountains and expeditions

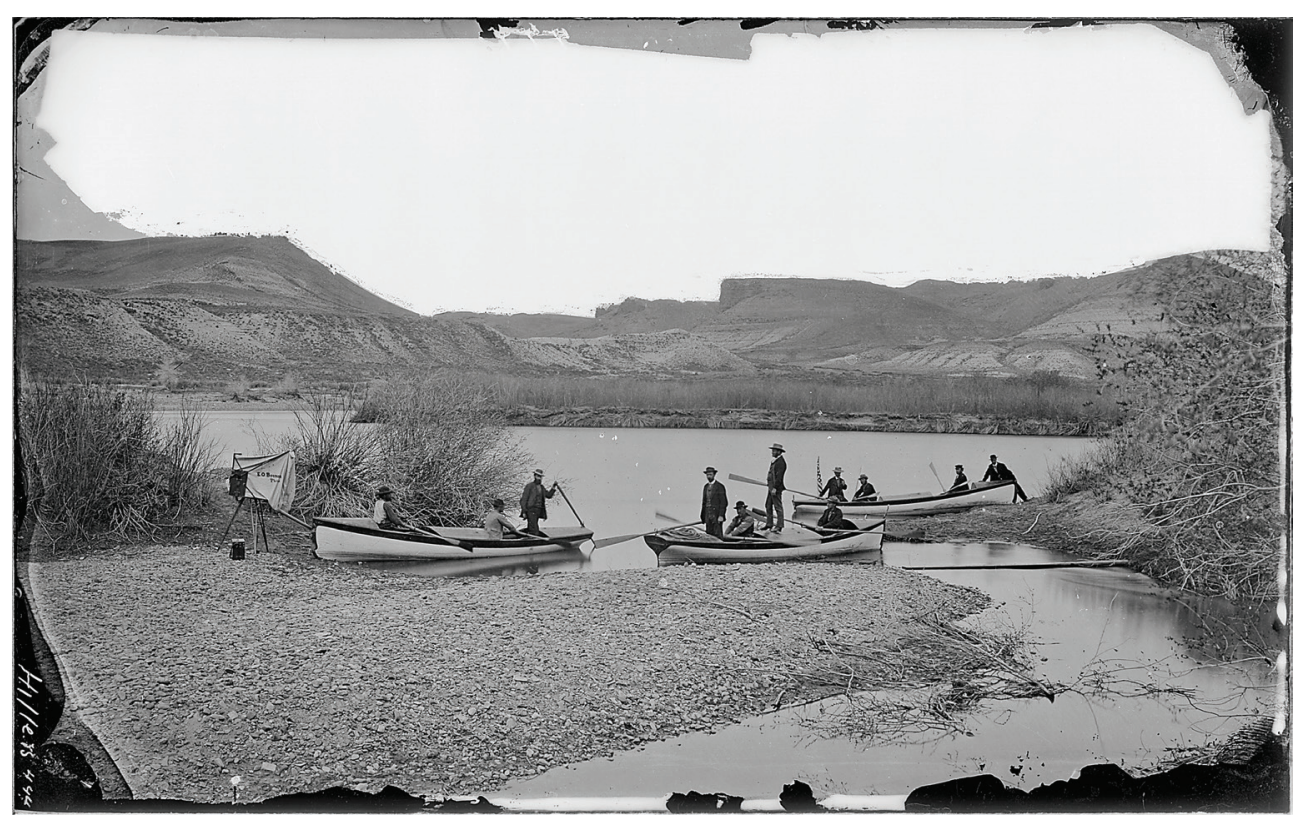

Figure 2. Members of the Powell expedition preparing to leave from the Green River Station in the Wyoming territory. It was during Powell's excursions through the aridlands of the western United States that inspired many of the ideas that he proposed for the region as the Director (1881-1894) of the United States Geological Survey. 
down the Green and Colorado Rivers produced new and foundational readings of the American West (Fig. 2). One of Powell's many biographers, Donald Worster, describes him as "the first prominent figure to think realistically about the nature of the West, to point to its essential aridity, and to ask what that scarcity of a vital resource might imply for settlement, progress, wealth, and power." "11 Powell spent many years working to answer this question, beginning during his excursions through the western United States and later as Director (1881-1894) of the United States Geological Survey (USGS).

In 1878, nearly fifteen years before Noble's proclamation of a "magic wand," Powell published his "Report on the Lands of the Arid Region of the United States, with a More Detailed Account of the Lands of Utah" in which he documented observations of his travels and suggestions for the management of the aridlands. Undergirding his descriptions of the physical characteristics of the region, Powell issued an urgent warning to Congress that national expansion would be severely limited by the ecological realities of aridity. In his report, Powell predicted that no more than 3\% of the lands west of the 100th meridian would be irrigable and proposed that land laws be reimagined in accordance with patterns more suitable to the ecology of the region. ${ }^{12}$ Instead of standardized 160 -acre rectangular land parcels granted by the Homestead Act (1862) - a size and geometry he believed to be ineffective in the West's harsh climate, he proposed two, interdependent forms of homesteading: irrigation districts organized around small farms, and grazing districts organized around larger livestock ranches. ${ }^{13}$ Communities of farms and ranches would share and collectively manage land, resources, wealth, and, most of all, water. In his "Report," Powell was explicit about the social and political collaboration necessary for the success of arid land cultivation, an approach still applicable and relevant to today's conditions.

Published in 1890 as part of the USGS Annual Report, Powell revealed his Map of the Arid Region of the United States, Showing Drainage Districts. The map illustrated how Powell's ideas could be physically mapped onto geographic space by proposing the formation of settlements around watersheds rather than arbitrary rectilinear boundaries. Radical in its proposition, Powell's map explicitly advocated for an entirely new lifestyle in which the patterns of society were choreographed in sync with the region's hydrologic flows. Today, Powell's proposal provides valuable insights for present and future planning in two interconnected ways. First, Powell describes a new spatial system for water management that recognizes the strong relationship between political boundaries, physical infrastructure, and societal organization. Powell's recommendation to draw geopolitical boundaries in response to the flow of water is useful in the current day context of both water scarcity and abundance, in that it makes water sources and its fluctuating rates and quantities highly visible. Second, the visibility of water and its environmental and infrastructural 
systems necessitates a new form of governance and management. Powell believed that the aridlands should be designed, planned, and managed with fundamentally different philosophies and politics to more effectively account for the scarcity of water. He understood that water in this part of the country must be regarded as both part of an already-functioning ecological system and an active participant in the production of a new type of aridland society. Restructuring of power away from top-down management and technocratic strategies towards a more flexible and localized system requires a reevaluation of conventional water rights, land use patterns, and localized data production. Powell's proposal was rejected by the 1893 International Irrigation Congress, one of the main decision-making bodies governing the aridlands, and aridland development continued as it was originally planned. ${ }^{14}$ Typical homesteads remained standardized in 160-acre parcels, eventually doubling and then quadrupling in size to cope with the arid conditions and to ensure economic viability. Surveyors drew political boundaries as orthogonal geometries that remained divorced from geological conditions. In doing so, water was privatized and the watershed was largely ignored as an organizing logic. Though Powell's plan was never implemented and development in the aridlands was planned and executed with little acknowledgement of the geography's ecological realities, it is useful to reintroduce the ideas of societal development around existing quantities and movements of water in our current context of the climate emergency, increased populations, and higher demands for water. Honoring the boundaries of the aridland watersheds produces a new geography in which the hydrologic system dictates the type of spatial, political, economic, and social systems at play within it.

\section{DIVIDING LAND BY WATER FLOW}

\section{Powell's Map of the Arid Region of the United States, Showing Drainage} Districts shows the western part of the United States as a brightly-colored tapestry of interlocking organic shapes, which mark the watersheds of each major river and stream in the region and were, therefore, firmly grounded by topography and elevation. Given that access to water was the limiting factor for the development of arid lands, Powell believed the watershed should be the political, social, and economic unit for life west of the 100th meridian. And, because water does not flow in straight lines and the ground is not flat, Powell recognized that the parceling of land into gridded rectangles, as instituted in other parts of the country, would prove to be inefficient in the context of aridity. Instead, Powell proposed that lands be divided into parcels created directly by the flow of water: "the lands along the streams are not valuable for agricultural purposes in continuous bodies or squares, but only in irrigable tracts governed by the levels of meandering canals which carry the water for irrigation." ${ }^{15}$ Beyond the desire to allow water drainage to guide land divisions, Powell advocated that communities parcel the land themselves so they could "mutually protect each other from the rapacity of individuals." 16 The ideas that land in the West might be communally organized and nonrectilinearly parceled were profoundly new concepts for white settlers in the 
American West, especially in the context of the nineteenth-century efforts to federally manage land and promote the nation's agrarian empire.

Powell believed that the arid lands were valuable only when irrigated or converted to grazing pastures through collective management; as a result, defining the relationship between land, water, and governance was critical to Powell's scheme: "Practically, all values inhere in the water, and an equitable division of the waters can be made only by a wise system of parceling the lands; and the people in organized bodies can well be trusted with this right, while individuals could not thus be trusted." 17 In Powell's conception of human nature, equality could be achieved through communal accountability, and, as such, space was to be governed in that manner as well. To that end, Powell's plan was motivated by his belief that the West required a political system based on the watershed instead of on incremental bureaucratic claims. Mapping source points of the West's water, how it flowed through the landscape, and its areas of drainage would also generate the boundaries of regional and local government. Each watershed would act as a unified whole; in Powell's words, "a commonwealth within itself." 18 In his vision, existing and proposed state boundaries would dissolve, leaving behind a patchwork of organic shapes to represent "self-organizing" socio-political units, allowing the watershed to generate society's principal governmental entity.

\section{REVISITING WATERSHED AS SOCIO-POLITICAL BOUNDARY, TODAY}

Powell's proposition that society's political and economic structures should be directly linked to ecological systems provides an insightful path forward in the face of today's growing climate crisis. In many respects, reorganizing lands that are immensely dependent on water - and simultaneously defined by its scarcity - around the hydrologic flows and patterns seems like an obvious proposal (Fig. 3). ${ }^{19}$ However, the resistance that such a radical proposal will face today will be even stronger than when first proposed by Powell. Yet, given the severity of climate change and the commensurate social challenges that it will bring, there is an undeniable need for big plans that attempt to fundamentally restructure society through acknowledgments of its inherent connections with the environment. Today, policy and spatial planning proposals that tackle climate change through the lens of social and economic justice are beginning to gain traction as essential steps in defining the scope and scale of the socio-ecological problems that must be addressed moving forward..$^{20}$ These proposals are definitive signals that American society and leadership acknowledge the inherent connections between climate, systemic inequality, global and national economics, and major infrastructural projects. Despite a growing public consensus in favor of such proposals, the political and economic leverage needed to implement such plans will require long-term support and cooperation from federal, state, and local leadership, enormous amounts of financial investment, and the unsettling of well-established 

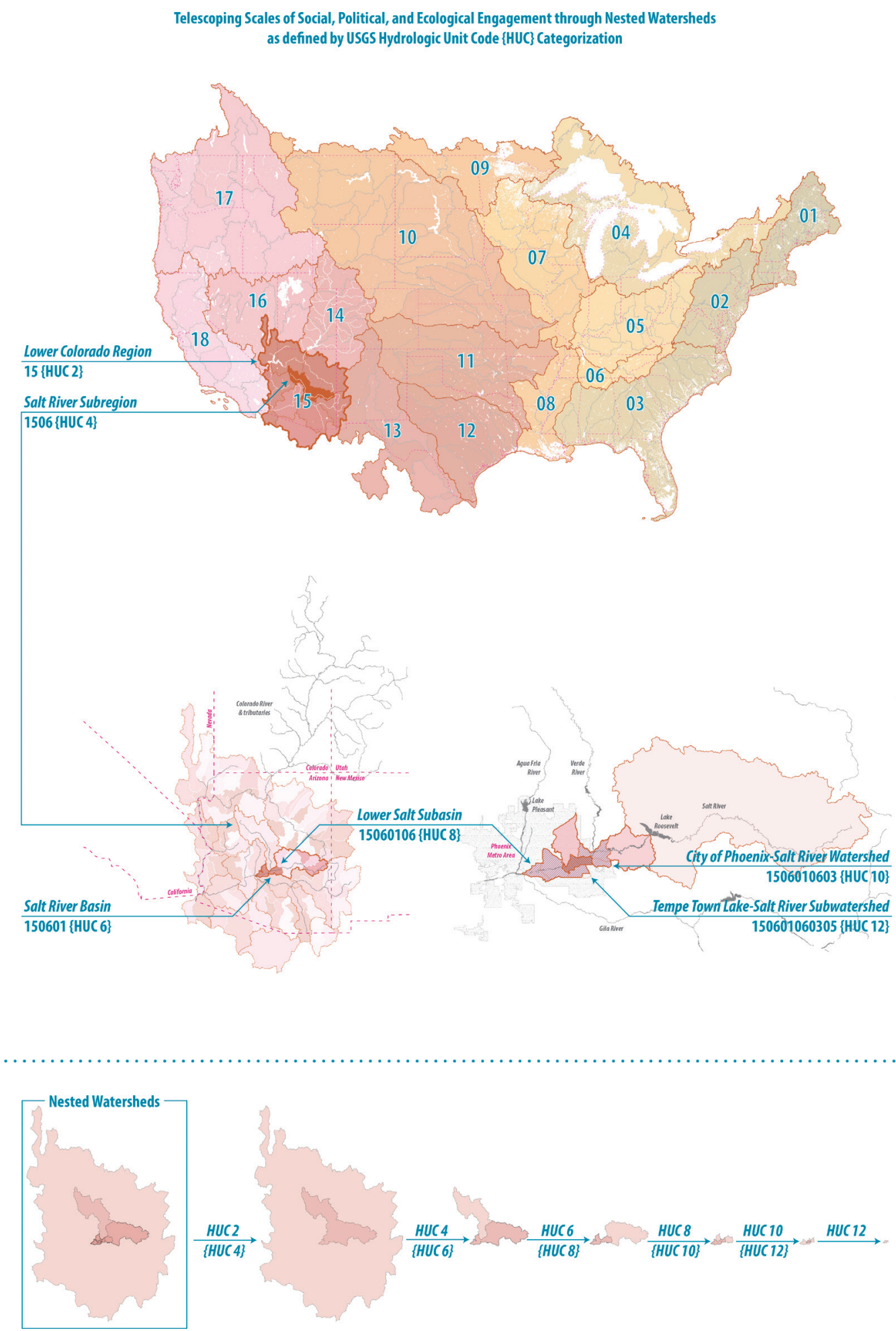

$\{H \cup C 6\}$

HUC 6

$\{H U C 8\}$

HUC 8

HUC 10 $\stackrel{\text { HUC } 12}{\longrightarrow}$

Figure 3. In the face of drier climates and growing populations in America's aridlands, revisiting Powell's proposal provides an exciting method for how the region might transition into a more resilient future. Organizing the region around its water, and specifically using the USGS's Hydrological Unit Code classification system, allows for telescoping scales of socio-political and ecological engagement within the region. Nested scales instigate different types of engagement between social, cultural, political, and economic processes that are guided by the specific conditions at each scale as well as its adjacent scales. Mapping is an essential method to examine systems at multiple scales and conditions. 
traditions for how the environment is managed and designed in favor of new and innovative approaches. ${ }^{21}$

The implementation of a large-scale plan to radically reshape life in the American West requires a phased and incremental approach at multiple, nested scales and necessitates a co-production of the region between top-down planning and bottom-up citizen participation. Planners and landscape architects, especially at regional and territorial scales, are highlyskilled in proposing how environmental, economic, and political systems can intersect in meaningful ways but need significant engagement with communities to provide insight into how those large-scale systems manifest at the local level. Similarly, bottom-up citizen participation is essential for thinking about the specific needs of particular communities and people but require the support of large-scale planners and landscape architects to create change at scales comparable to the socio-environmental challenges they aim to impact. This way of engaging with landscape systems requires a more intimate and immediate relationship between local stakeholders, their water sources, and the institutional structures that control the management of water. Further, by making the systems, cycles, and unpredictability of water both integral in management plans and visible to the public sphere, a culture is produced more in-tune with the realities of aridland ecologies. Such reinforced hydro-social relations make evident the need to manage water in response to local needs and resource flows that are constantly changing both spatially and temporally. This co-production between planning and participation, thus, must reject top-down, centralized management, and all practices that are applied to the watershed must remain flexible and open to evolving dynamics and conditions. It then follows that at the scale of the watershed, and its nested micro-sheds, a local collective of users self-manage territorial resources they determine who can access, withdraw, and consume water, and under which conditions; they address competing uses, assess and manage risk and conflict, and adapt policies and processes in the face of fluctuating hydrological and political change. By restructuring both social and political organizations around the flow of water systems, the significance of water as a human right that is to be shared amongst governing communities would become a prominent governing principle for the use of water, displacing current demands by individuals, cities, and industries.

\section{WATER RIGHTS AS HUMAN RIGHT}

Central to Powell's proposal was the defense of public water and its equitable distribution. He believed that the relationship between land and water was foundational to successful development of the aridlands, arguing that the right to water should be attached to the land where it is being used, and that those who build the infrastructure to move water should not have priority to the water. Powell saw water rights inhered to the land as an essential strategy to reject implementing a system where those with the 
most money and power were entitled to the most water. ${ }^{22}$ To this end, he vehemently opposed privatizing water, cautioning:

If in the eagerness for present development, a land and water system shall grow up in which the practical control of agriculture shall fall into the hands of water companies, evils will result therefrom that generations may not be able to correct, and the very men who are now lauded as benefactors to the country will, in the ungovernable reaction which is sure to come, be denounced as oppressors of the people. ${ }^{23}$

Powell astutely anticipated that if water policy did not reject privatizing water, water distribution would eventually be dominated by the rich and powerful. By structuring its management communally, water would be conserved, kept clean, and distributed fairly.

Today, water rights in the arid West do not align with Powell's vision, and consequently, his predictions have proved accurate. In the West's current system of the "Prior Appropriation Doctrine," water rights are not automatically guaranteed to the owner of the land on which water runs through, as Powell believed they should be. Rather, rights are granted to the first person that uses water for "beneficial" purposes (defined historically as agriculture, industry, and domestic uses). ${ }^{24}$ Each water right has an assigned yearly allocation and appropriation date (the time at which water was first used for "beneficial" purposes) - the user with the earliest appropriation date ("senior appropriator") may divert their entire allocation from the water source; then the next earliest appropriator takes water; and so on chronologically down the line of water rights until either the last right has been fulfilled or the water runs out. In times of drought or decreased water flow, those with later appropriation dates ("junior appropriators") often receive only a portion of their yearly allocation and sometimes none at all. The inequity between those who are granted enough water and those given little or none is likely to intensify given forecasts for significant decreases in surface water flow and groundwater recharge.$^{25}$ In this system, those who have more water are richer and more powerful, and vice versa. Those who are socially disenfranchised are often those that have less access to water. ${ }^{26}$ The inequity of this dynamic plays out conspicuously in two types of scenarios. First, in the case of many Indigenous nations living on reservations, despite often having a legal right to high allocation quantities and early appropriation dates, numerous accounts show that water rights relating to Indigenous communities have often been unobserved; and that those in control of water distribution, and the legal processes intended to hold them accountable, have historically turned a blind eye when white colonial settlers have used water sources which were legally reserved for Indigenous nations and communities. ${ }^{27}$ Second, small farmers and ranchers are often disadvantaged by large-scale industrial agriculture corporations that dominate the landscape by purchasing and combining 
small parcels of land into massive swathes and paying exorbitant prices for senior water rights. The result is that smaller farmers, even those with senior water rights, are put into direct competition with corporations that have more financial resources, more land, water, and production potential, and have access to a wider network of markets and higher profit margins. Subsequently, smaller operations are increasingly unable to keep up and are often forced to sell land and water rights to lucrative corporations, further sustaining industrial agriculture and the structures of hierarchical water rights that enable it.

The "first in time, first in right" system that currently structures the West's water rights has proved to be highly contentious. If instead, the watershed boundary dictated both the water sources and the constituents who have access to and control of that water, conflicts could be avoided through a more grounded and flexible water management system. In this scenario, water rights would not be determined by land ownership or water usage but rather through an ethos in which water is believed to be a human right, shared equally among all within the watershed boundary. ${ }^{28}$ Further, the system would need to formally acknowledge that those using the water within the watershed often have the most accurate information regarding its quantity and quality; and that the allocation and distribution of water is determined and monitored by those who are reliant on it and who are deeply invested in its sustained health and availability. In this way, the system is not constrained by the accuracy of information obtained by a distant bureaucratic agency, but by real-time data collected through on the ground sources. It is clear that as the climate becomes more erratic and extreme, the water rights system will need to be much more dynamic and less deterministic than the current system in order to respond to environmental variation and societal needs over time. To allow for such adaptability, those within the watershed will need to have the authority to evaluate, assess, and institute change as necessary to their water policies, allocation mechanisms, and water and land use patterns.

\section{REEVALUATING HOW LAND IS USED}

Powell identified three types of land uses - irrigated farms, pastures, and timberlands - that had already been incentivized by federal policies and would substantially contribute to the economic and social development of the arid lands. According to Powell, classifying the lands for their bestsuited use must be based on topography, elevation, and proximity to a water supply. ${ }^{29}$ Powell's proposal was inherently a sectional survey of the region. Irrigated farms, in the lowlands, should receive water either from snowmelt or a proximal water source, and have agency in its distribution. ${ }^{30}$ In the highlands, the timberlands would supply building material and fuel for development within each watershed. In Powell's vision, all other lands non-irrigated and unsuitable to timber - would be deemed pasturelands for grazing cattle. These land classifications categorized ecology within each 
watershed district to create self-sustaining watershed economies and to build strong social connections with regional ecological characteristics and cycles.

Powell imagined that land use patterning in the arid West would center on the ecologies of place rather than on unrealistic economic expectations. Moving forward, land use typologies and zoning for the future of the aridlands will similarly need to be strongly connected with the ability for the ecological specificities of the watershed to accommodate it: detailed surveys of soil, planting, water flows, and weather events should directly correlate with the catalog of land use types supported in the watershed. Today, agriculture and urban development dominate the majority of land use in much of arid America (Fig. 4). While these land uses are integral to the current socio-political and economic conditions of the aridlands, predictions for future environmental and societal dynamics will limit their growth in a way that has been unseen before (Fig. 5). Limited water supplies will require reassessing the value of water-intensive monocultures, like alfalfa and corn, which currently account for nearly $50 \%$ of the aridland crops, according to the US Department of Agriculture..$^{31}$ Urban development will no longer be able to support the maintenance of golf courses, public fountains, household lawns, and private swimming pools. Instead, the conventions of land use planning will need to be fundamentally redefined not as single-use but as dynamic and responsive to seasonal variations, environmental limits, and population changes. Changes to land use planning will reverberate, dictating new ways of living. Recreation in the arid West will need to adapt to include activities that do not require waterintensive maintenance. And, the agricultural industry will need to introduce new crop species that thrive with less water; more flexible rotations that are choreographed with unpredictable and extreme seasonal variations; and new forms of infrastructure that distribute reduced quantities of water across the landscape (Fig. 6).

Using Powell's proposal as an opening to discuss more ecologicallyadaptive urban planning does not imply that Powell invented this approach, or was even the first to opine on it; but instead, that his proposal is one of the most comprehensive documents which suggests potential steps societal, political, and environmental - toward resilient human settlement and economic activity within the region's arid conditions. In fact, organizing communities around watershed boundaries was an idea most likely informed by and adapted from his interactions with the many Indigenous communities he encountered on his expeditions. Despite his extensive interaction with and reliance on the knowledge of Indigenous communities, Powell focused his attention on improving the lives of white settler colonists who had appropriated land through protracted violence with Indigenous communities. On his travels through the Colorado and Green Rivers, he had relied heavily upon the local knowledge and lived experiences of Indigenous people he met along the way, but his proposal does not, in any 

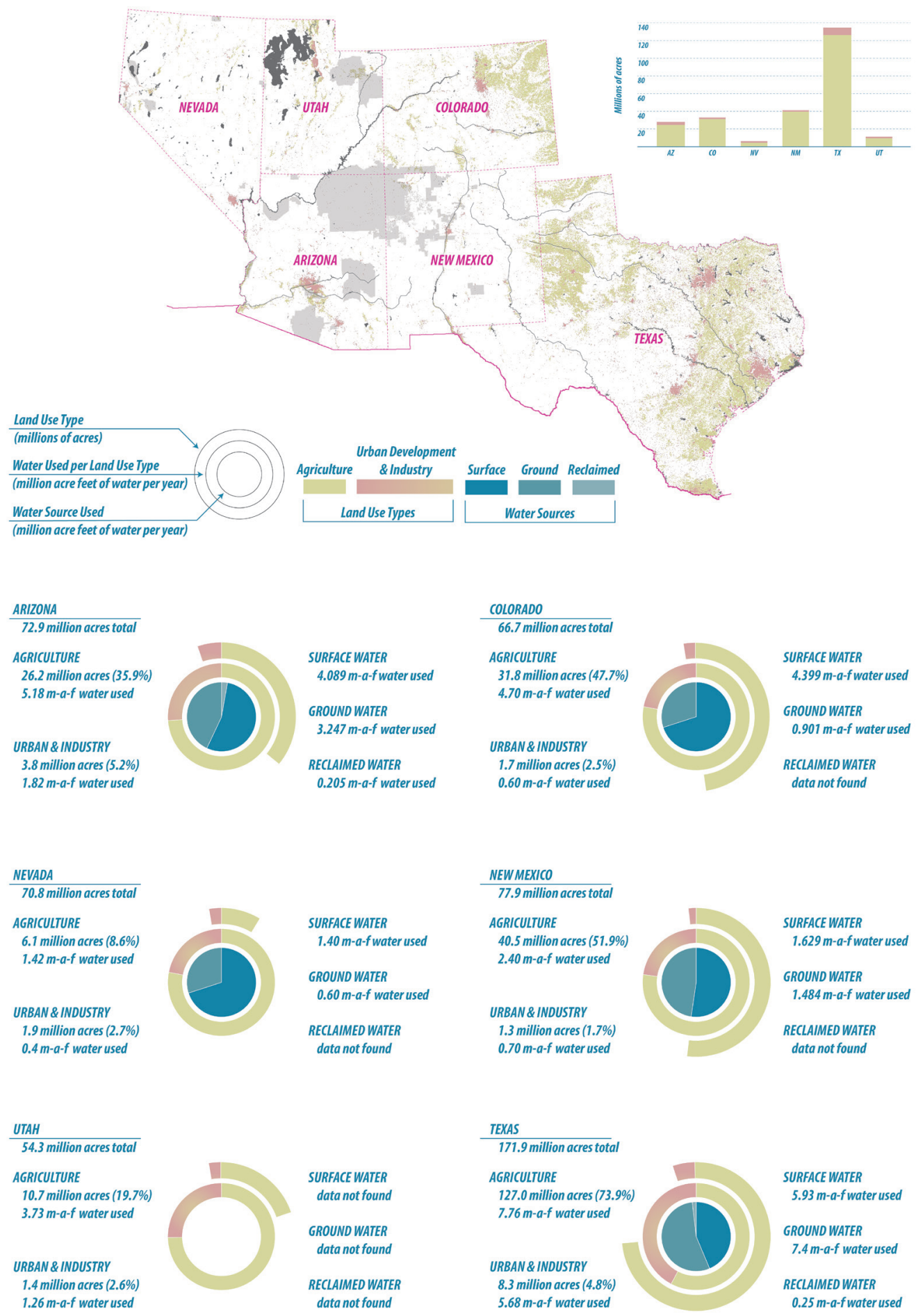

Figure 4. Today, the aridlands are dominated by unsustainable land use typologies. Millions of acres of land are dedicated to agriculture and unsustainable urban development which require more water than is available. In the future of drying climates, these land uses will become completely untenable in their current conditions. Imagining a future of these regions that transition away from the unregulated use of water is essential. These charts compare among six aridland states how land use typologies are related to the amount and source of water used. Notable is that the amount of land dedicated to agriculture in Texas (127 million acres $-51,4$ million ha) is more than that of all other five states combined (115.3 million acres $-46,7$ million ha). It is also worth noting that Texas has nearly five times as many acres dedicated to agriculture than Arizona, but only uses 1.5 times as much water. 

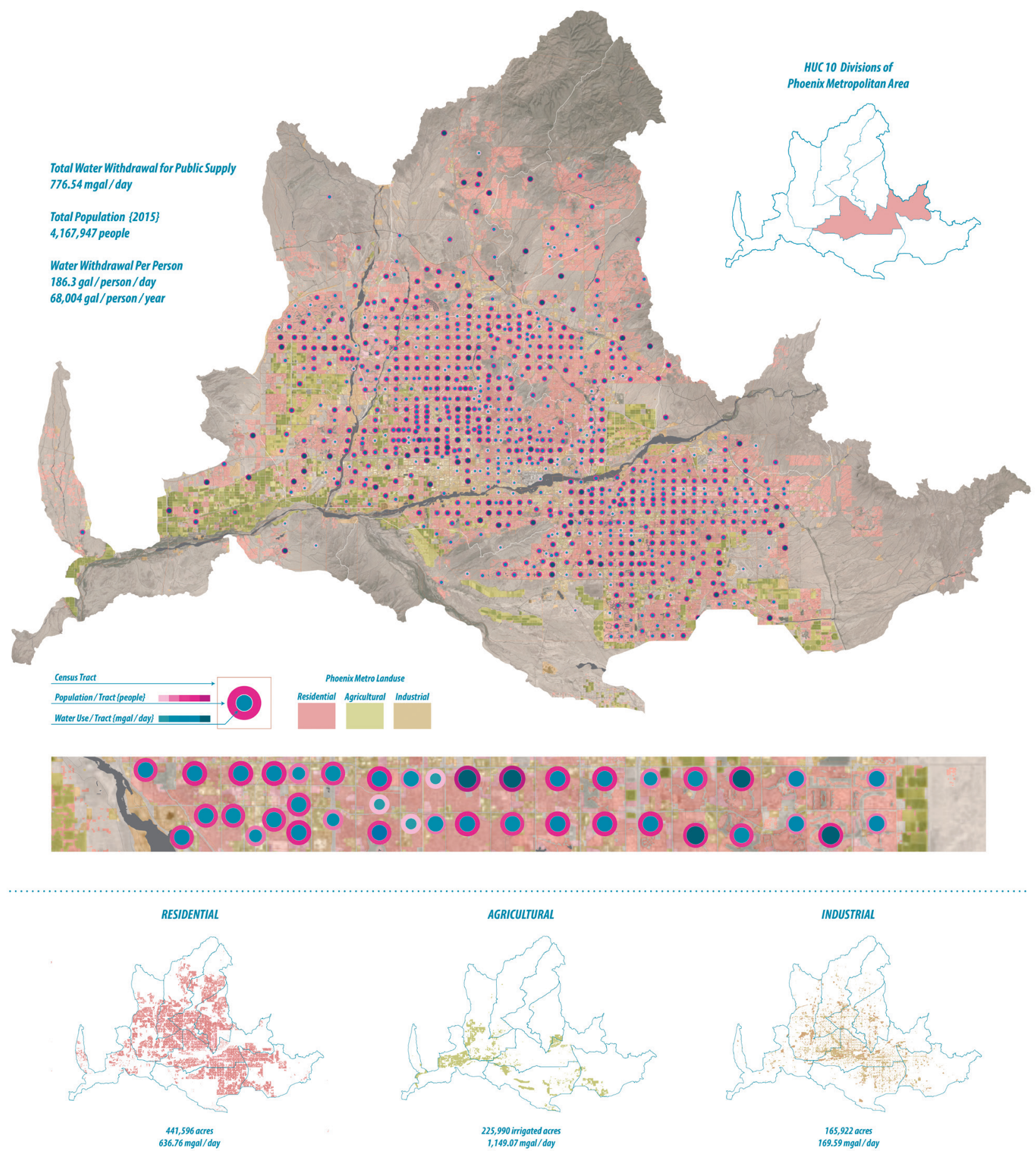

Figure 5. Through a careful analysis of the relationship between how much water is used to sustain urban development (gallons per person) and agricultural production (gallons per person), it is clear that the current patterns of water usage are already unsustainable as demands for water increase but sources and quantities decrease. Looking toward future planning, the specific conditions of each watershed, at multiple geographic scales, must dictate the scales of social, political, and infrastructural systems. At the scale of the region, the watersheds, and their adjacencies, determine patterns of land use and how those patterns are governed and managed. The Phoenix metropolitan area withdraws 776.54 million gallons (2.940 million liters) of water per day for public use; of that, over $80 \%(642.33$ million gallons $-2.431,5$ million liters) is used to sustain residential land use typologies. In Phoenix, approximately 225,000 acres (91,05 ha) of irrigated to support agricultural production with nearly 1,200 million gallons (4.542 million liters) of water used per day. 


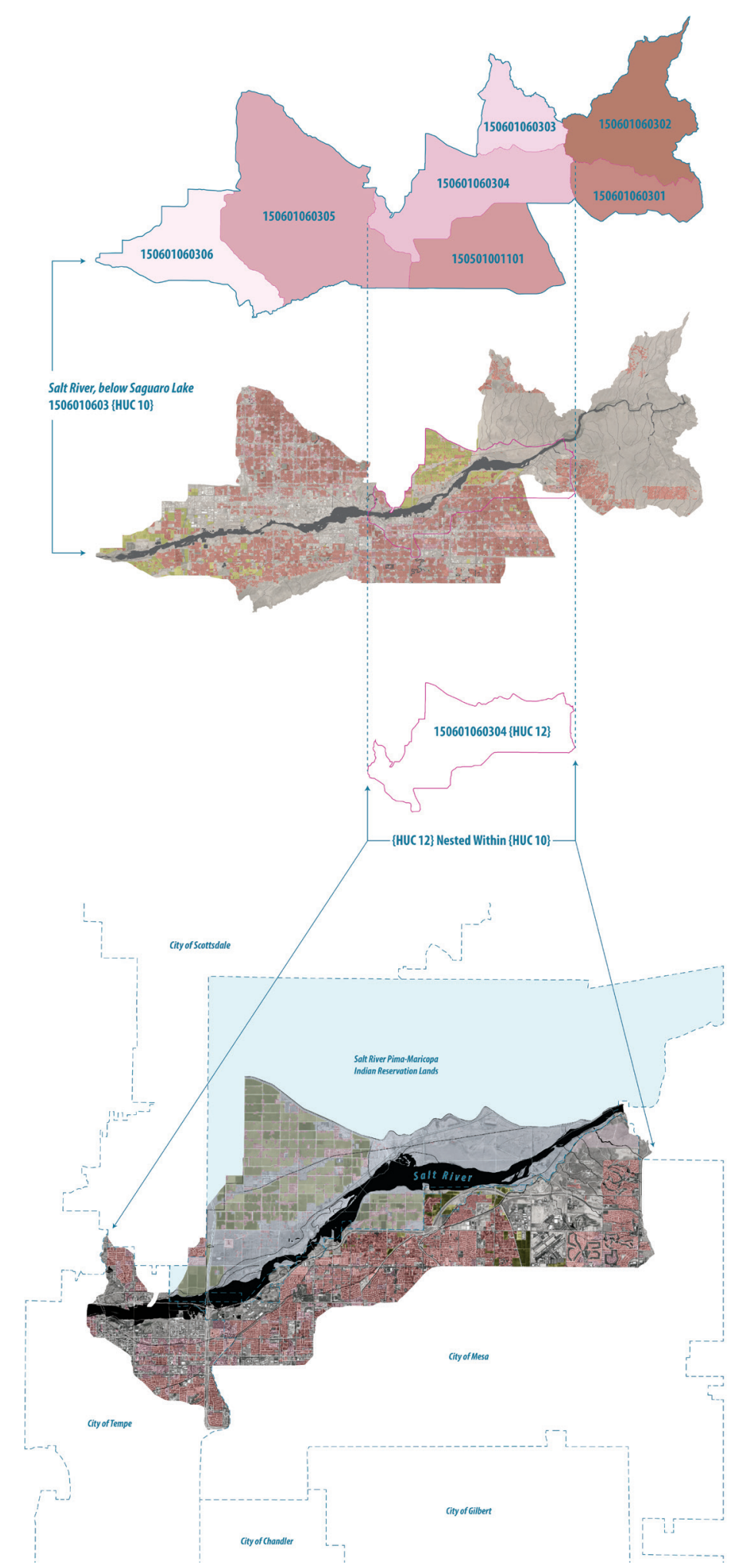

Figure 6. At smaller scales, the specific characteristics and conditions of the landscape become more significant in dictating how water is distributed, accessed, and used.

Additionally, these smaller scales (HUC 10 and HUC 12) require more close coordination between adjacent HUCs in order to choreograph and ensure the equitable distribution and management of water sources. Especially when water sources are shared among diverse entities (such as Indigenous nations), social and economic justice must be at the center of water management strategies and policy. 
meaningful way, address the dispossession of their lands, nor propose that their presence or practices on the land be honored and incorporated into plans for the West's development. ${ }^{32}$ While celebrating Powell's beliefs of the strong connections between society and environment, it is also necessary to call out his colonial mindset in relation to Indigenous peoples, especially if his proposal might be the basis of thinking more expansively about more equitable futures of the aridlands. This critique of Powell is not merely a statement to be footnoted as a shortcoming in his proposal but rather an opening to think critically about how a reimagined future of water and land management in the aridlands can meaningfully address and recompense Indigenous nations and communities that have been continuously disenfranchised by aridland development.

\section{DRY FUTURES: RESILIENCY IN THE FACE OF THE CLIMATE EMERGENCY}

Although John Noble's belief that irrigation would be the "magic wand" to cure the realities of the desert can easily be dismissed for its simplistic view of the West's ecological complexities, contemporary water infrastructure has continued to embody Noble's original national strategy to occupy and cultivate the American West through the attempted reversal of its hydrology. John Wesley Powell's proposal, alternatively, presents an approach to designing arid lands that reflects the logic of its ecology rather than its politics. Seen through contemporary lenses of resiliency and green infrastructure, Powell's unrealized proposal was a squandered chance to reframe aridity as an opportunity for innovation rather than a condition to be reversed. Powell's proposal continues to provide an alternative to conventional approaches to aridity, and adeptly identifies opportunities for overlaying ecological planning and communal social values.

Undergirding all of Powell's recommendations for development in the West was his belief in the power of cultivating deep, local, place-based knowledge. Accordingly, his primary objective as Director (1881-1894) of the Unites States Geological Survey was to extensively map the West in anticipation that once citizens had information about the places they lived, they would then become more engaged, invested, and democratic in their use of its resources. While one might argue that the West, then and now, is commanded by real estate speculation and resource exploitation, Powell's confidence in a public supported by knowledge is an aspiration that resonates today in the face of privatized water, arrangements between public and private interests, and pervasive systemic inequity. Above all, Powell was dedicated to preparing settler Americans to learn to live with aridity. $\mathrm{He}$ imagined the arid West as a place with great potential if development played to advantages of the existing hydrology and ecology. Both empirical, datadriven analysis and real-time accounts from those within the region are required in order to be effective enough to address the climate emergency. These principles are perhaps even more relevant in today's climate condition. 
It is time to reflect more seriously, strategically, and radically on the core question that arises from Powell's proposal: what cultural attitudes, values, policies, and technologies are needed to shift toward more ecologically resilient and equitable communities in the arid American West? In order to answer this question, it is essential to assess and evaluate already-existing technologies and in-place policies. Looking to the past offers critical clues for how we can accomplish goals of resiliency and adaptability in the face of changing climates. To this end, historical narratives must become more deeply embedded and generative to the design process. These narratives are constructed from observable, tangible acts as much as the immaterial and invisible; each is important to recognize the ways our current paradigms are the consequence of what has come before. As Rebecca Solnit has recognized,

History is shaped by the groundswells and common dreams that single acts and moments only represent. It's a landscape more complicated than commensurate cause and effect. Politics is a surface in which transformation comes about as much because of pervasive changes in the depths of the collective imagination as because of visible acts. ${ }^{33}$

As it pertains to the American West, Solnit's argument is especially relevant given how fundamentally regulation and water policies have shaped - and continue to shape - the physical lay of the land, distribution of resources, societal organization, and economic success in the region. Much of the politics that define the arid West have been in service of retreating from aridity, rather than leaning into its potentials. There is much evidence which shows that avoiding the realities of the region's ecology leads to situations that are not nearly as efficient or equitable in the long term as they need be, specifically because natural resources, in general, are becoming ever more scarce and water, in particular, is both the limiting factor of the region and non-renewable.

The first step toward realizing a new aridland paradigm is to upend the perception that dry ecologies are inherently valueless and in need of fundamental transformations. Only after shifting the dominant cultural narrative toward one that celebrates the ecological richness of aridity is it possible to enact new spatial policies, technologies, and lifestyles that adequately address and meaningfully engage with the enormous geographic and long-term temporal scales of the climate crisis. Considering ecological systems as social, political, and economic, as Powell suggests, produces a more resilient and adaptable future amidst inevitable and unpredictable change. Our environment directly impacts how we live and how our societies are structured, and our social organization intimates our values toward and interaction with nature. As anthropologist Gregory Bateson reminds us, "We are not outside the ecology for which we planwe are always and inevitably a part of it." ${ }^{34}$ If we are going to live in a 
place where the climate is extreme and where water is our most precious resource, we must prime ourselves for a dry future. While it may seem futile to propose that land management in the West be reorganized around watershed boundaries, the need to address rising aridity is imminent. Therefore, it is imperative to reframe and contemplate a future without reliance on costly techno-deterministic designs that marshal more water from further regions and which bring with them endemic conflicts over water rights.

\section{Notes}

1. Donald Worster, Rivers of Empire: Water, Aridity, and the Growth of the American West (Oxford, UK: Oxford University Press, 1992), xi.

2. Here, I use the term "actant" in reference to Latour's definitions of non-human agents that contribute to our understanding of the world. Bruno Latour, "On Actor-Network Theory: A Few Clarifications," Soziale Welt 47, no. 4 (1996): 369-81.

3. Alisher Mirzabaev, Jianguo Wu, Jason Evans, Felipe García -Oliva, Ismail Abdel Galil Hussein, Muhammad Mohsin lqbal, Joyce Kimutai, Tony Knowles, Fancisco Meza, Dalila Nedjraoui, Fasil Tena, Murat Türkes, Ranses José Vázquez, and Mark Weltz, "Desertification," in "Climate Change and Land: An IPCC Special Report on Climate Change, Desertification, Land Degradation, Sustainable Land Management, Food Security, and Greenhouse Gas Fluxes in Rerrestrial Ecosystems" (2019): 251, https://www.ipcc.ch/site/ assets/uploads/sites/4/2019/11/06_Chapter-3.pdf.

4. Intergovernmental Panel on Climate Change (IPCC), "Summary for Policymakers," in "Global Warming of $1.5^{\circ} \mathrm{C}$. An IPCC Special Report on the Impacts of Global Warming of $1.5^{\circ} \mathrm{C}$ above Pre-Industrial Levels and Related Global Greenhouse Gas Emission Pathways, in the Context of Strengthening the Global Response to the Threat of Climate Change, Sustainable Development, and Efforts to Eradicate Poverty" (2018): 4, https://www.ipcc.ch/sr15/chapter/spm/. 5. Gensuo Jia, Elena Shevliakova, Paulo Artaxo, Nathalie De Noblet-Ducoudré, Richard Houghton, Joanna House, Kaoru Kitajima, Christopher Lennard, Alexander Popp, Andrey Sirin, Raman Sukumar, and Louis Verchot, "Land-Climate Interactions" in "Climate Change and Land": 142, https://www.ipcc.ch/site/assets/uploads/sites/4/2019/11/05_Chapter-2.pdf. 6. Ibid., 146-47.

7. Almut Arneth, Fatima Denton, Fahmuddin Agus, Aziz Elbehri, Karlheinz Erb, Balgis Osman Elasha, Mohammad Rahimi, Mark Rounsevell, Adrian Spence, and Riccardo Valentini, "Framing and Context," in "Climate Change and Land": 86, https://www.ipcc.ch/site/assets/uploads/sites/4/2019/12/04_Chapter-1.pdf. 8. Ibid., 88.

9. Donald Pisani has written extensively on the history of the Reclamation Era (approximately 1890-1920), in which most federal policies regarding the American West were dedicated to transforming arid lands from their inherent aridity into lands that could be productive for agriculture. Of the most notable figures during this time were Frederick Jackson Turner, William Ellsworth Smythe, Frederick Haynes Newell, and Francis G. Newlands. See more in Donald J. Pisani, Water and American Government: The Reclamation Bureau, National Water Policy, and the West, 1902-1935 (Berkeley CA, USA: University of California Press, 2002) and Donald J. Pisani, To Reclaim a Divided West: Water, Law, and Public Policy, 18481902 (Albuquerque NM, USA: University of New Mexico Press, 1992).

10. Despite ever-present dryness, dependence on a continuous, reliable source of water coupled with an emerging confidence in techno-determinism, paved the way for engineering every major water source for productivity, predictability, and profitability. Hydro-enginnering projects, like the Hoover Dam and others, massively shifted the scale, intensity, and ambition of projects constructed throughout the West; today these major irrigation projects today are alone responsible for providing water and power to millions of people, sustaining growth and economic development in the West's urban centers, and feeding millions of acres of agriculture. 
11. Donald Worster, "A River Running West: Reflections on John Wesley Powell," Journal of Cultural Geography 26, no. 2 (June 1, 2009): 115, https://doi.org/10.1080/08873630903025055.

12. John Wesley Powell, "The Reclamation Idea (1878)," in American Environmentalism: Readings in Conservation History, ed. Roderick F. Nash, 3rd ed. (New York: McGraw-Hill, 1989), 65.

13. John Wesley Powell, "Report on the Arid Lands," in The Arid Lands, ed. Wallace Stegner (Lincoln NE, USA: Bison Books, 2004), 42.

14. John Wesley Powell, Seeing Things Whole: The Essential John Wesley Powell, ed. William deBuys (Washington DC: Island Press, 2001) 218.

15. Powell, "Report on the Arid Lands," 38.

16. Ibid.

17. Ibid.

18. Robert L. Dorman, A Word for Nature: Four Pioneering Environmental Advocates, 1845-

1913 (Chapel Hill NC, USA: University of North Carolina Press, 1998), 209.

19. A watershed-based approach to the management of water is by no means a new idea. Integrated Watershed (or Catchment Management) is a well-established method for addressing, analyzing, and governing water's quantity, quality, and dissemination in both arid and temperate regions. Many parts of Australia, India, and New Zealand, among others, have already adopted this approach for managing their waters and lands. The Integrated Catchment Management strategies in Australia's Murray-Darling Basin are some of the most successful examples of communities and governments (at all levels) working together to create long-term practices and policies for water management. See more in Zachary Bischoff-Mattson and Amanda Lynch, "Integrative Governance of Environmental Water in Australia's Murray-Darling Basin: Evolving Challenges and Emerging Pathways," Environmental Management 60 (2017): 41-56.

20. The Green New Deal (2018) is an example of one such proposal. In its current state, it is a policy resolution, not a policy plan, that pushes the federal government to develop and enact policies that meaningfully address the climate emergency through the lens of economic and social justice; and create low-carbon technologies, industries, and infrastructures. The Green New Deal proposes a fundamental transformation of existing socio-spatial, economic, and ecological systems. See more in Kian Goh, "Planning the Green New Deal: Climate Justice and the Politics of Sites and Scales," Journal of the American Planning Association (2020): 1-9. 21. Challenges to such proposals are plenty. In January 2018, Ryan Zinke, the then-Secretary of the Interior under President Donald Trump, recommended that the Interior Department be reorganized into watershed regions. Zinke stated, "Taking inspiration from Powell's concept of watersheds, we're looking at reshaping our current bureau-based regional system of management and moving to a system based on ecosystems, watersheds, and science" (US Department of the Interior, "Planning for the Next 100 Years," January 10, 2018, https:// www.doi.gov/employees/reorg/interior-planning-next-100-years). Critics claim that though the intention is noble, Zinke has failed to account for the time, money, and effort required to execute such a reorganization. Others have voiced skepticism that Zinke's plan does not take into account the nuances of ecology - in a letter to the Associate Press, Donald Worster notes that the proposal links regions that are ecologically different, while separating others that have shared features (Dan Elliott, "Despite Complaints, Interior

Boss Pushing Big Reorganization," Denver Post, February 14, 2018, https://www.denverpost.com/2018/02/14/ryan-zinke-interior-reorganization/).

22. Powell writes, "The 'user right' should attach to the land where used, not to the individual or company constructing the canals by which it is used. The right to the water should inhere in the land where it is used; the priority of usage should secure the right." Powell, "Report on the Arid Lands," 55.

23. Ibid., 53-54.

24. Christine A. Klein, "The Constitutional Mythology of Western Water Law," Virginia 000 Law Journal 14, no. 2 (1995): 343-80.

25. Eric P. Perramond, Unsettled Waters: Rights, Law, and Identity in the American West, (Berkeley CA, USA: University of California Press, 2018), 11-31.

26. This system of water management reinforces systems of private property and real estate speculation, which have proven to be inequitable systems. See more in Danika Cooper, "Waters Resist: Modernity, Aridity, and the Fight over Orme Dam," Journal of Architectural Education 74, no. 1 (2020): 37-47. 
27. Janet A. McDonnell, "Land and Water: Federal Irrigation Projects on Indian Reservations," in The Dispossession of the American Indian, 1887-1934 (Bloomington IN, USA: Indiana University Press, 1991), 71-86.

28. In 2002, the United Nations Committee on Economic, Social, and Human Rights officially recognized water as a universal human right, writing, "The human right to water is indispensable for leading a life in human dignity. It is a prerequisite for the realization of other human rights... The right to water clearly falls within the category of guarantees essential for securing an adequate standard of living, particularly since it is one of the most fundamental conditions for survival" (Committee on Economic, Social, and Cultural Rights, 29th session, November 2002). However, there is growing awareness that water should not only be valued for its potential to support human life, but also because of its life-sustaining qualities for other living organisms and ecosystems. See Mariano Gomez-Luque and Ghazal Jafari, eds., New Geographies 09: Posthuman (New York: Actar, 2018) and Astrida Neimanis, Bodies of Water: Posthuman Feminist Phenomenology (New York: Bloomsbury, 2017).

29. Powell, "Report on the Arid Lands," 6.

30. According to Powell, "If these lands are to be reserved for actual settlers, in small quantities, to provide homes for poor men, on the principle involved in the homestead laws, a general law should be enacted under which a number of persons would be able to organize and settle on irrigable districts, and establish their own rules and regulations for the use of the water and subdivision of these lands, but in obedience to the general provisions of the land." Powell, "Report on the Arid Lands," 27.

31. US Department of Agriculture, Economic Research Service, "Irrigation \& Water Use," September 23, 2019, https://www.ers.usda.gov/topics/farm-practices-management/irrigationwater-use/.

32. Through his position as the founding director of the federal Bureau of Ethnology, Powell was deeply engaged with the collection of anthropological and ethnographic research about the Indigenous nations of the United States. His work on Indigenous cultures and languages, however, was, at best, an attempt to reconstruct a pre-colonial history of the United States.

See more in D. Leedom Shaul, "Linguistic Natural History: John Wesley Powell and the Classification of American Languages," Journal of the Southwest 41, no. 3 (1999): 297-310. And, at its worst, the Bureau of Ethnology was a federal department intent of compiling knowledge about Indigenous nations and their languages that could be used to the government's advantage during treaty negotiations. Under Powell, the Bureau of Ethnology's research was heavily influenced by the leading nineteenth-century anthropologist Lewis Henry Morgan's theory of cultural evolution, which classified societies into three evolutionary categories - "savagery," "barbarism," and "civilization." Powell believed that nearly all Indigenous groups should be placed into the "savage" stage and that the development of the West would catalyze the end of their primitive lifestyles. See more about Powell and his engagement with Morgan's theories in Richard B. Woodbury and Nathalie F. S. Woodbury, "The Rise and Fall of the Bureau of American Ethnology," Journal of the Southwest 41, no. 3 (1999): 283-96.

33. Rebecca Solnit, "Hope in the Dark," in Transforming Terror: Remembering the South of the World, eds. Karin Lofthus Carrington and Susan Griffin (Berkeley CA, USA: University of California Press, 2011), 298-99.

34. Gregory Bateson, Steps to an Ecology of Mind: Collected Essays in Anthropology,

Psychiatry, Evolution and Epistemology (Chicago: University of Chicago Press, 2000), 512.

\section{Acknowledgments}

This work was generously supported by the Hellman Family Fellows Fund and initial ideas were workshopped as part of the Mellon-Global Urban Humanities fellowship at the University of California, Berkeley where my colleagues provided invaluable critical feedback. I also wish to thank my research assistants Elizabeth Sturr and Jessica Colvin for their essential support in data collection and visualization. I am particularly grateful to Zannah Mæ Matson for her insightful comments and editorial eye. 


\section{Credits}

Figure 1: image retrieved from John Wesley Powell, Arid Region of the United States, Showing Drainage Districts, 1890 (U.S. Smithsonian Collection).

Figure 2: image retrieved from John K. Hillers, Green River Station, Wyoming, 1871

(U.S. National Archives) - https://catalog.archives.gov/id/517806.

Figures 3, 4, 6: images created by the Author.

Figure 5: image created by the Author; Data from: USGS, Water Use Data web portal - https://waterdata.usgs.gov/az/nwis/water_use?format=html_table\&rdb_ compression=file\&wu_area $=$ County\&wu_year $=2015 \& w u \_c o u n t y=013 \& w u_{-}$ category=ALL\&wu_county_nms=Maricopa\%2BCounty\&wu_category_nms=-ALL\%2BCategories--.

Danika Cooper is an Assistant Professor of Landscape Architecture and Environmental Planning at the University of California, Berkeley. Her teaching and research centers around the geopolitics of scarcity, alternative water ontologies, and designs for resiliency in the world's arid regions. Her work incorporates historiographical research methods, landscape architecture design and visualization, and theories of urban infrastructure to evaluate and design arid landscape for environmental and social justice. Specifically, Cooper is focused on finding alternatives to the prevailing nineteenth-century conceptions that the aridlands should be overturned through technocratic solutions and neoliberal politics. Her work has been published and exhibited across the world, and she has practiced in both the United States and India. E-mail: danikacooper@berkeley.edu 